\title{
Nutritional evaluation of differently processed piper (Canavalia plagiosperma) seed meal (CPSM) in broiler starter diets
}

Esonu, B.O., Izukanne, R.O*., Udedibie, A.B.I. and Okeudo, N. J.

Department of Animal Science and Technology, Federal University of Technology Owerri

*Corresponding author: E-mail richardizukanne@yahoo.com

\begin{abstract}
A feeding trial was conducted with the aim of improving the nutritive value of Canavalia plagiosperma seedmeal (CPSM) for broiler starter rations. One hundred and fifty kilogram (150kg) of Canavalia plagiosperma seeds were cracked and thereafter divided into three batches. Two batches were soaked in water while the third batch was soaked in alkaline solution ( $2 \%$ palm bunch ash by weight of the cracked seeds) in different plastic containers for 48 hours, before draining off the soaking solutions. The first, second and third batches were boiled in different pots for 1 hour, 2 hours and 1 hour respectively. They were separately sundried for $4-5$ days and milled to produce cracked soaked in water and boiled for 1 hour (CSWB1), cracked soaked in water and boiled for 2 hours (CSWB2) and cracked soaked in alkaline and boiled for 1 hour (CSAB1), Canavalia plagiosperma seedmeals (CPSM) respectively. The meals were used to formulate seven broiler starter rations at $0 \%, 10 \%$ and $20 \%$ dietary inclusion, levels, respectively (Table 3). Each of the seven broiler starter rations was fed to a group of 42 one-week-old broiler chicks for 28 days, to evaluate the performance of the birds and economic implications. There were significant differences $(P<0.05)$ in daily feed intake, daily body weight gain and feed conversion ratio. Results from this trial suggests that CPSM could be included in broiler starter diets up to $20 \%$ without adverse effect if cracked, soaked in water and boiled for an hour.
\end{abstract}

Keywords: Canavalia plagiosperma seeds, broiler starter, cracked, soaked, alkaline, boiled.

\section{Introduction}

The poultry industry in Nigeria is undergoing a turbulent period and some farmers have closed down and others forced to reduce their production capacity due to high cost of feed and feedstuffs (Esonu et al., 2013). The major reason for this scarcity and increased cost of poultry feed has been attributed to increased competition between man and livestock for major feedstuffs such as maize, groundnut and many others, which supply the protein and other nutritional needs of the birds (Okorie, 2006). Ogunji (2003) reported that the problem is more with proteinous feeds. The utilization of unconventional feed sources especially those that are not directly edible to man will help to produce balanced and economic diets for the birds and reduce dependence on the conventional sources. Tuleun and Patric (2007) reported that increased usage of conventional feed sources resulted in high cost, shortage and scarcity of feedstuffs such as soybean and groundnut cake. The high cost and irregular supply of the conventional feed sources have stimulated researches into unconventional feed materials that are biologically qualitative (Akpodiete, 2008) locally available, less expensive and nonedible to man such as Canavalia plagiosperma seeds (Ekenyem et al., 2008).

Canavalia plagiosperma is a high forage 
and high seed yielding tropical legume with high energy and high protein content and quality (Odoemelam, 2007). The plant is a relatively unknown legume that is neither used as human food nor as animal feed in Nigeria and yields up to 3 tons per hectare in experimental study (Agbabiaka, 1999), with seed about five times the size of soybean (Odoemelam and Ahamefule, 2006). The crude protein content of ripe seed ranged from $26-36 \%$ on dry matter basis and the protein has relatively good amino acid profile (Anumni, 2010). Currently the use of legume has been limited by the presence of some antinutritional factors like trypsin inhibitor, hydrogen cyanide, tannins and most especially concanavalin A (Esonu et al., 2013). This study evaluated the possibilities of improving the feeding value of Canavalia plagiosperma seeds for broiler starter chicks through some locally adaptable processing techniques.

\section{Materials and methods}

\section{Location of the experiments}

The research was conducted at the Teaching and Research Farm of the School of Agriculture and Agricultural Technology, Federal University of Technology Owerri, Imo State, Nigeria.

Sources and processing of the test materials The Canavalia plagiosperma seeds for the research were obtained from IkwuanoUmuahia in Abia State of Nigeria. The Canavalia plagiosperma seeds were cracked and thereafter divided into three batches. Two batches were soaked in water while the third batch was soaked in alkaline solution ( $2 \%$ palm bunch ash by weight of the seeds) in different plastic containers for 48 hours, before draining off the soaking solutions. The first, second and third batches were boiled in different pots for 1 hour, 2 hours and 1 hour respectively(Time of boiling was taken from when the material submerged in water in the pot started boiling). They were separately sundried for 4 - 5 days and milled to produce cracked soaked in water and boiled for 1 hour (CSWB1), cracked soaked in water and boiled for 2 hours (CSWB2) and cracked soaked in alkaline and boiled for 1 hour (CSAB1), Canavalia plagiosperma seedmeals (CPSM) respectively. The sundried seeds were separately bagged, later milled in a hammer mill with sieve size of $3.36 \mathrm{~mm}$ to produce the seed meals and stored for the trial. Samples of the raw, CSWB1, CSWB2 and CSAB1seedmeals respectively were analysed, using standard methods (AOAC 1990) to determine the nutrients composition (Table 1)

\section{Experimental diets}

Seven (7) experimental broiler starter diets were formulated such that the differently processed Canavalia plagiosperma seedmeals CSWB1, CSWB2 and CSAB1, were included at $0 \%, 10 \%$ and $20 \%$ dietary levels respectively as shown on Table 2 . Feed and water were offered ad-libitum.

Experimental birds and design

Two hundred and ninety-four (294), oneweek-old Marshal Strain broiler chicks were divided into seven groups of 42 birds each. Each group was further sub-divided into three replicates of 14 birds each and randomly assigned to the seven treatment diets in a completely randomized design (CRD). During the 28 days trial period, routine medications were applied, litter changed regularly and other routine poultry management practices maintained.

\section{Datacollection}

The birds were weighed at the beginning of the trial period and subsequently on weekly basis. Feed intake was determined by obtaining the difference between the quantity of feed offered and quantity left 
Table 1: Proximate and Phytochemical analysis of the differently processed Canavalia plagiosperma seed meal (\% Dry matter)

\begin{tabular}{lcccc} 
Components & Raw & CSWB1 & CSWB2 & CSAB1 \\
\hline Dry matter (\%) & 80.65 & 81.65 & 81.15 & 79.25 \\
Crude protein & 36.11 & 26.12 & 33.93 & 26.25 \\
Crude fibre & 5.15 & 6.30 & 6.80 & 7.10 \\
Ether extracts & 5.48 & 3.41 & 3.16 & 4.67 \\
Ash & 1.80 & 1.40 & 1.60 & 2.10 \\
NFE & 51.46 & 62.77 & 52.51 & 59.88 \\
Phytochemical Analysis & & & & \\
Concanavalin A(iu) & 8.820 & 3.690 & 3.690 & 2.880 \\
Saponin (\%) & 4.500 & 2.000 & 2.000 & 0.500 \\
Glycoside(\%) & 0.114 & 0.106 & 0.110 & 0.107 \\
Alkaloid (\%) & 8.520 & 5.600 & 6.800 & 4.440 \\
Lectin (iu) & 9.800 & 4.100 & 4.100 & 3.200 \\
Tannin (\%) & 0.640 & 0.120 & 0.133 & 0.133 \\
\hline
\end{tabular}

\footnotetext{
NB:- $\quad$ CSWB1 $=$ Cracked, soaked in water for 48 hours and boiled for thour CSWB2 $=$ Cracked, soaked in water for 48 hours and boiled for 2 hours $\mathrm{CSABI}=$ Cracked, soaked in alkaline solution and boiled for 1 hour

Raw $=$ raw or unprocessed Canavalia plagiosperma seedmeal
}

Table 2: Gross Composition of experimental broiler starter diets

\begin{tabular}{|c|c|c|c|c|c|c|c|}
\hline \multirow[b]{2}{*}{ Ingredients } & CSWB1 & \multicolumn{6}{|c|}{ Inclusion levels of differently processed CPSM } \\
\hline & $0 \%$ & $10 \%$ & $20 \%$ & $10 \%$ & $20 \%$ & $10 \%$ & $20 \%$ \\
\hline Maize & 50.00 & 50.00 & 50.00 & 50.00 & 50.00 & 50.00 & 50.00 \\
\hline Soybean Meal & 30.00 & 20.00 & 12.00 & 20.00 & 12.00 & 20.00 & 12.00 \\
\hline CPSM $^{*}$ & 0.00 & 10.00 & 20.00 & 10.00 & 20.00 & 10.00 & 20.00 \\
\hline Fish Meal & 3.00 & 3.00 & 3.00 & 3.00 & 3.00 & 3.00 & 3.00 \\
\hline Palm Kernel Cake & 2.50 & 2.50 & 2.50 & 2.50 & 2.50 & 2.50 & 2.50 \\
\hline Wheat Offal & 10.00 & 10.00 & 8.00 & 10.00 & 8.00 & 10.00 & 8.00 \\
\hline Bone Meal & 3.50 & 3.50 & 3.50 & 3.50 & 3.50 & 3.50 & 3.50 \\
\hline TM/Vit. Premix ** & 0.25 & 0.25 & 0.25 & 0.25 & 0.25 & 0.25 & 0.25 \\
\hline Lysine & 0.25 & 0.25 & 0.25 & 0.25 & 0.25 & 0.25 & 0.25 \\
\hline Methionine & 0.25 & 0.25 & 0.25 & 0.25 & 0.25 & 0.25 & 0.25 \\
\hline Common Salt & 0.25 & 0.25 & 0.25 & 0.25 & 0.25 & 0.25 & 0.25 \\
\hline Total & 100.00 & 100.00 & 100.00 & 100.00 & 100.00 & 100.00 & 100.00 \\
\hline
\end{tabular}

Calculated analysis

\begin{tabular}{lrrrrrrr} 
& & & & & & & \\
Crude protein & 22.26 & 21.15 & 20.58 & 21.15 & 20.58 & 21.15 & 20.58 \\
Crude fibre & 4.52 & 4.58 & 5.01 & 4.58 & 5.01 & 4.58 & 5.01 \\
Ether extract & 3.80 & 3.70 & 3.83 & 3.70 & 3.83 & 3.70 & 3.83 \\
$\mathrm{Ca}$ & 1.48 & 1.49 & 1.50 & 1.49 & 1.50 & 1.49 & 1.50 \\
$\mathrm{P}$ & 0.95 & 0.92 & 0.93 & 0.92 & 0.93 & 0.92 & 0.93 \\
$\mathrm{ME}(\mathrm{Kcal} / \mathrm{Kg})$ & 2837.02 & 2912.12 & 3090.42 & 2912.12 & 3090.42 & 2912.12 & 3090.42 \\
\hline
\end{tabular}

* CPSM = processed Canavalia plagiosperma seedmeal

** To provide the following per $\mathrm{kg}$ of feed: Vit. A, 10,000iu; Vit. D, 1,500iu; Vit. K, $2 \mathrm{mg}$; riboflavin, 3 mg; Pantothenic acid, $6 \mathrm{mg}$; Niacin, $15 \mathrm{mg}$; Choline chloride, $3 \mathrm{mg} ; \mathrm{Vit}$. $B_{12}, 0.08 \mathrm{mg}$; Folic acid, $4 \mathrm{mg} ; \mathrm{Mn}, 8 \mathrm{mg} ; \mathrm{Zn}, 0.5 \mathrm{mg}$ : Iodine, 1.0 $\mathrm{mg} ; \mathrm{Co} 1.2 \mathrm{mg}$; $\mathrm{Cu}, 10 \mathrm{mg} ; \mathrm{Fe}, 20 \mathrm{mg}$;

CSWB $1=$ Cracked, soaked in water for $48 \mathrm{hrs}$ and boiled for $1 \mathrm{hr}$ CSWB2 $=$ Cracked, soaked in water for 48 hrs and boiled for 2 hrs 
over after 24 hours the next morning. Weight gain was determined by the difference between the initial weight and final weight. Daily weight gain was calculated by dividing the weight gain by the number of days the trial lasted. Feed conversion ratio was computed by dividing the average daily feed intake by the average daily body weight gain. Feed cost per kg was calculated by summing up the feed ingredients cost of $100 \mathrm{~kg}$ and divided by 100. Feed cost per $\mathrm{kg}$ meat produced was calculated by multiplying the feed cost per $\mathrm{Kg}$ by the feed conversion ratio. The trial lasted 28 days.

\section{Statistical analysis}

Data collected were subjected to analysis of ariance (ANOVA) as outlined by nedecor and Cochran (1980). Where gnificant differences were observed tween treatments, means were compared ing Duncan's New Multiple Range test DNMRT) as outlined by Obi (1990).

\section{Results and Discussion}

The proximate composition of the raw, CSWB1, CSWB2 and CSAB1 were shown on Table 1. The CP values of the raw and processed Canavalia plagiosperma seedmeal $(36.11-26.12 \%)$ were higher $(\mathrm{P}<0.05)$ than that reported for most legumes (17 - 30\%) (Seena et al., 2006). This protein value makes Canavalia plagiosperma seed a probable supplement to cereal based diets with $\mathrm{CP}$ of $8.55 \%$ or below (Sagarika et al., 1999) and alternative vegetable protein source than most other unconventional tropical legumes (Seena et al., 2006). The CP of the processed Canavalia seedmeal decreased due to solubilisation and loss of nitrogenous compounds. The CSWB2 had higher CP value than CSWB1 and CSAB1 respectively. This agrees with the report of
Akanji, et al. (2003) that prolonged boiling periods increased $\mathrm{CP}$ values due to destruction of anti-nutrients contained in the seeds.

The Crude fibre content falls within the reported range $(6.49-12.87 \%)$ of other Canavalia spp (Udedibie, 1990 and Esonu, 1996). The Crude fibre is less than that of $C$. ensiformis $(8.5 \%)$, C. gladiata $(12.8 \%)$ and Canavalia maritama $(17.3 \%)$ (Seena $e t$ al., 2006). The lipid values ranged from $5.48-3.40 \%$ respectively for raw and processed CSPM respectively. This is in line with other unconventional legumes such as swordbean (2.94\%) (Akinmutimi., 2004), Atylosias carabaevides (4.56\%) Neonotonia wightii (4.64 \%) (Arinathon et al., 2003).The appropriate level of ether extract (Ether extract) suggests that the seeds should be considered as an oil seed as it compares with groundnut $(6.0 \%)$ and higher than soybean $(3.5 \%)$ reported by Pfizer Nutrients Master Plan (1995). The NFE values recorded compared favourably with swordbean $(50.38 \%)$, Mucuna conchinchinesis $(51.86 \%)$ and jackbean $(60.20 \%)$ as reported by Udedibie (1990), Esonu et al. (1997), Esonu et al.,( 2001), Ukachukwu (2000) and Akinmutimi (2004) respectively for raw jackbean and swordbean. Ash content values were lower than that of Canavalia ensiformis (4.64\%), Canavalia gladiata $(3.72 \%)$ and Canavalia carthatica (3.36\%) (Seena et al., 2006). The increased feed intake of the birds on the diets containing CSWB1, CSWB2 and $\mathrm{CSAB} 1$ over the control could be due to high fibre content and solubilisation of some nutrients. Birds must therefore eat to meet their energy requirement to sustain growth and development hence increased feed intake. This agrees with earlier reports (Esonu et al., 2004; Esonu et al., 2007).

Data on the performance and economic analysis of the starter broiler chicks fed the 
differently processed CPSM were shown on Tables 3 and 4 respectively. Birds on $10 \%$ CSWB1 dietary level of inclusion performed best $(\mathrm{P}<0.05)$ in term of feed intake and feed conversion ratio. This performance could be attributed to higher protein quality content of the test material due to detoxification of the ANFs in the processing methods (Table 1). It was observed that the daily weight gain dropped as the level of the test material increased except with the group on $20 \%$ CSWB1. This confirms that anti-nutritional factors reduced growth rate and feed conversion efficiency (Tamir and Alumot, 1996). However, birds on $10 \%$ inclusion levels of CPSM performed better $(\mathrm{P}<0.05)$ than their counterparts on $20 \%$ dietary inclusion levels. Based on the trial the birds on $20 \%$ CSWB1 dietary inclusion level recorded the least cost $(190.48)$ in $\mathrm{N} / \mathrm{Kg}$ meat produced than the other groups.

\section{Conclusion}

This study suggests that cracked soaked in water and boiled for 1 hour processing method could improve the nutritive value of Canavalia plagiosperma seeds for broiler starter at $20 \%$ dietary level.

\section{Reference.}

Agbabiaka, L.A. 1999. Comparative performance of broilers fed diet containing variously processed Jackbean meal. M.Sc. Thesis, Federal University of Technology Owerri.

Table 3: Performance of starter broilers fed different levels of Canavalia plagiosperma seedmeals (CPSM)

\begin{tabular}{|c|c|c|c|c|c|c|c|c|}
\hline \multirow{3}{*}{ Parameter } & \multicolumn{8}{|c|}{ Inclusion levels of differently processed CPSM } \\
\hline & \multicolumn{3}{|c|}{ CSWB1 } & \multicolumn{2}{|c|}{$\underline{\text { CSWB2 }}$} & \multicolumn{2}{|c|}{ CSAB1 } & \multirow[b]{2}{*}{ SEM } \\
\hline & $0 \%$ & $10 \%$ & $20 \%$ & $10 \%$ & $20 \%$ & $10 \%$ & $20 \%$ & \\
\hline nitial body weight $(\mathrm{g})$ & & & & & & & & \\
\hline Fina & & & & & & 1116.67 & & 89. \\
\hline Body weight ga & $889.06^{b}$ & $966.67^{\mathrm{ab}}$ & $1025.00^{\mathrm{a}}$ & $998.50^{\mathrm{a}}$ & $812.50^{b}$ & $966.67^{\mathrm{ab}}$ & $778.83^{\mathrm{b}}$ & 29. \\
\hline ight gain $(\mathrm{g})$ & $31.75^{b}$ & $34.52^{\text {ab }}$ & $36.61^{\mathrm{a}}$ & $35.66^{\mathrm{a}}$ & $29.02^{\mathrm{c}}$ & $34.52^{\text {ab }}$ & $27.82^{\circ}$ & \\
\hline Daily feed intake $(\mathrm{g})$ & 83. $18^{\mathrm{c}}$ & $85.17^{\mathrm{bc}}$ & $95.44^{\mathrm{a}}$ & $88.52^{b}$ & $83.90^{\mathrm{c}}$ & $88.31^{b}$ & $81.81^{\circ}$ & \\
\hline & $2.62^{b}$ & $2.47^{c}$ & $2.6 \mathrm{I}^{\mathrm{b}}$ & $2.48^{\mathrm{c}}$ & $2.89^{a}$ & $2.56^{b}$ & $2.94^{a}$ & \\
\hline Mortality & 0.00 & 0.00 & 0.00 & 0.00 & 0.00 & 0.00 & 0.00 & \\
\hline
\end{tabular}

nbe : means within rows with different superscripts are significantly $(\mathrm{P}<0.05)$ different.

SEM - Standard Error of the Mean.

Table 4: Economic analysis of different dietary inclusion levels of processed CPSM Inclusion levels of differently processed CPSM

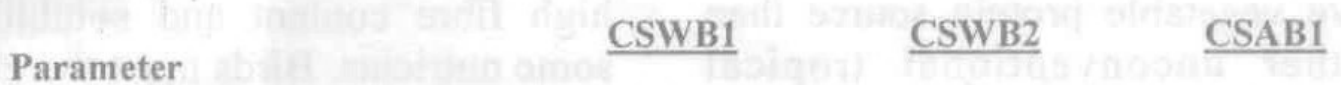

Parameter

\begin{tabular}{rrrrrrr}
$0 \%$ & $10 \%$ & $20 \%$ & $10 \%$ & $20 \%$ & $10 \%$ & $20 \%$ \\
\hline 95.78 & 81.78 & 72.98 & 81.78 & 72.98 & 81.78 & 72.98 \\
- & 14.62 & 23.81 & 14.62 & 23.81 & 14.62 & 23.81 \\
250.94 & 202.00 & 190.48 & 202.81 & 210.91 & 209.36 & 214.56 \\
\hline
\end{tabular}

CPSM = Canavalia plagiosperma seedmeal 
Akanji, A.M., A.O. Ologbobo, I.O. Emiola, T.A. Adedeji and O.S. Adedeji, 2003. The effect of processing on haemagglutinin and other anti-nutritional factors in Jackbean (Canavalia ensiformis ( $L$ ) $(D C)$. Proceeding of the $28^{\text {th }}$ Annual Conference of Nig. Soc. for Animal Production 189-193.

Akinmutimi, A.H. 2004. Evaluation of swordbean (Canavalia gladiata) as an alternative feed resources for boiler chickens. Ph.D. thesis, College of Animal Science, Michael Okpara University of Agriculture, Umudike, Abia State, Nigeria.

Akpodiete, O.J. 2008. Performance of laying birds fed enzymes supplemented palm kernel cake (P.K.C.) based diet. Animal Production Research Advances 4 (1): 42-46.

Anumni, P.E., 2010. Evaluation of Canavalia plagiosperma seedmeal as feed ingredients in poultry diets. M.Sc. Thesis, FUTO, Nigeria.

Arinathan, V., Mohan, V.R. and De Britto, A.J., 2003. Chemical composition of certain tribal pulses in South India. Int. J. Food Sci. and Nutri. 54:209-217.

Association of Official Analytical Chemists (AOAC), 1990 ).Official Methods of Analysis, $15^{\text {th }}$ ed. Washington DC.

Ekenyem, B.U. Ndubuisi, E.C. and Anyanwu, L., 2008. Effect of partial replacement of sorghum (Sorghum bicolor) dust for maize (Zea mays) in broiler starter ration. Animal Production Research Advances 4 (2): $88-91$.

Esonu, B.O., 1996. Studies on the method of improving the nutritive value of Jackbean (C. ensiformis) for poultry industry. Ph.D. thesis, Federal University of Technology, Owerri.

Esonu, B.O., Udedibie, A.B.I., and Herbert, U., 1997. Nutritional evaluation of raw jackbeans (Canavalia ensiformis) for weaner rabbits. DeltaAgric., 4: 18 - 24.

Esonu, B.O., Emenalom, O.O., Udedibie, A.B.I., Udoh, H., Ekpor, C.F., Okoli, I.C. and Iheukwumere, F.C., 2001. Performance and blood chemistry of weaner pigs fed raw mucuna bean. Trop. Anim. Prod. Invest. 4:49-54.

Esonu, B.O., J.C. Azubuike, O.O. Emenalom, E.B. Etuk, I.C. Okoli, H.O Uku and C.S. Nneji, 2004. Effect of enzyme supplementation on the performance of boiler finisher fed Microdesmis pubercula leaf meal. Int. J. Poultry Sci. 3:112-114.

Esonu, B.O., Nnaemeka, A.A., Azubuike, J.C., Uchegbu, M.C., Ezeokeke, C.T., 2007. Performance and economic analysis of boiler starter fed dried rumen digesta. Int. J. Agric. and Rural Dev. 9(1A): 77 - 79.

Esonu, B.O., Anumni, P.E., Udedibie, A.B. I., Emenalom, O.O., Etuk, E.B., Odoemelam, V. and Okolie, K. C. 2013. Evaluation of two-stage cooked Canavalia plagiosperma (piper) seed meal as feed ingredients in layer diets. Nig. J. Anim. Sci. 15: 95-103.

Obi, I.U., 1990.Statistical Methods of detecting differences between treatment means. $2^{\text {nd }}$ edition, Snaap Press Enugu, Nigeria.

Odoemelam, V.U., 2007. Proximate composition, anti-nutritional properties and mineral assay of raw and processed Canavalia plagiosperma seed. M. Sc. Thesis, Department of Animal Production 
and Management, Michael Okpara University of Agriculture, Umudike, Abia State, Nigeria.

Odoemelam, V.U. and Ahamefule, F.O., 2006. Effect of dehulling on proximate composition, antinutritional properties and mineral contents of $C$. plagiosperma seeds. Trop. J.Anim. Prod. 31 (2): 167-175.

Ogunji, J.O., 2003. Alternative protein sources in diets of farmed tilapia.. Review Series B, 74(9): 23 - 32 .

Okorie, K.C., 2006. Evaluation of Jacaranda mimosifolio T. (Stans) leaf meal as ingredients in finisher broiler diet. Performance carcass and organ weight characteristics. Animal Production Research Advances 2 (1): 44- 49 .

Pfizer Nutrient Master Plan (PNMP), 1995. Tropical crops dicotyledons. Longman Group Ltd, London $1^{\text {st }}$ ed. pp 242-245.

Sagarita, E., Enol, R.J. and Baboo, M.N., 1999. Proximate composition, mineral and amino acid content of mature Canavalia gladiata seeds. Food Chemistry 66: 115 - 119.

Seena, S., K. R. Sridhar, A. B. Arun, and Chiu-Chung, Y., 2006..Effect of roasting and pressure-cooking on nutritional and protein quality of seeds of mangrove legume Canavalia cathartica from South-West Coast of India. J. Food Composition and Analysis 19:284-293.

Snedecor, G.W. and W.G. Cochran, 1980. Statistical Methods. $6^{\mathrm{TH}}$ ed. The Iowa State Univ. Press Ames. Iowa,

Tamir, M. and Alumot, E., 1996. Inhibition of digestive enzymes by condensed tannins of green and ripe carots. J. Sci. Food and Agric. 20: 199 $-202$.

Tuleun, C.D. and J.P. Patric, 2007. Effect of duration of cooking Mucuna utilis seeds on proximate analysis, levels of anti-nutritional factors and performance of broiler chicks. Paper presented at the $32^{\text {nd }}$ Annual Conference of the Nig. Soc. Anim. Prod., Calabar, 45.

Udedibie, A.B.I., 1990. Nutritional evaluation of jackbean ( $C$. ensiformis) for the Nigeria Poultry Industry. AMBIO, 19:361 - 365.

Ukachukwu, S.N., 2000. Chemical and nutritional evaluation of Mucuna conchinchinesis (lyon's beans) as an alternative protein ingredient in broiler diets. Ph.D thesis, Department of Animal Science University of Nigeria Nsukka, Nigeria. 